\title{
堤防法面における地域性を考慮した在来草本による緑化 事例
}

\section{大和田 塁 ${ }^{* 1}$ ) - 佐々木祐司 1) - 岡村俊邦 1)}

\section{1）北海道工業大学大学院工学研究科}

\section{1. はじめに}

法面緑化の目的とは植生によって裸地状態の法面を被覆 し，浸食を制御して荒廃を防ぐことである。また，それと同 時に周辺の景観と連続性を保ち, 全体的な景観の中で違和感 の生じさせないものとする事も重要な目的である ${ }^{6) 。 こ れ ら ~}$ を早期に達成寸るために, 従来は成長の早い外来種を用いて 緑化が行われてきた。しかし近年では上記の目的以外にも生 物多樣性の保全の必要性が求められ, 在来種を用いた緑化も 行われつつある1)。生物多椂性の保全には, 生態系の多椂性, 種の多様性，遺伝子の多様性という３つのレベルでの多様性 の確保が必要であるとされている5)。しかし現状ではまだ在 来種を用いた緑化で遺伝子の多㥞性(地域性)までを考慮して いる事例は少ない 2,3)。また，在来種を用いていても，施工し やすい特定の種のみの場合や，外来種と併用して施工されて いる場合が多い1)。

そこで野の花や山菜として親しまれている多様な在来種を 用いて，河川や堤防を身近なものとすることを目的とした堤 防法面の緑化試験を行った。従来草本の導入には吹付工等の 播種工が一般的である。しかしこの事例では多様な種を確実 に定着させるため, ポット苗による植栽で施工した。

本報告はこの事例の植栽後 3 年間の追跡調查の結果を報告

\footnotetext{
* 連絡先著者: E-mail : q10401@hit.ac.jp $\quad \bar{T} 006-8585$ 北海道札幌市手稲区前田 7 条 15 丁目 4-1
}

\section{するものである。}

\section{2. 試験地概要}

試験地は北海道石狩郡当別町にある石狩川水系茨戸川の上 部湖盆に位置する美登江の石狩川法面緑化試験堤防である (図-1)。法面方位は西北西で, 勾配は 10 度, 法長は $12 \mathrm{~m}$, 法面延長は $25 \mathrm{~m}$ で, ここは堤防に水防資材の土砂を盛った 法面である。試験地では植栽した草本が生長するまでの間の 法面保護機能を補うためにマルチングを施した。

\section{3. 材料と方法}

\section{1 育苗方法}

試験地では生態学的混播・混植法 7)を応用して施工した。 生態学的混播・混植法とは地域住民参加により, その地域で 採取した多種多椂な種子を用いて, ポット苗を養成, 植栽す ることにより自然に近い樹林の再生を行う工法である。

この事例では，エゾミソ八ギ，ギョウジャニンニク等の多 年生草本を用いた。育苗に使用した種子は全て石狩川下流域 と同じ石狩川水系の豊平川流域で採取したものである。使用 した全草本を表-1に示す。全て山菜として食されたり, 美し い花を咲かせたりする等, 昔から親しまれ, 地域住民にとっ て魅力のある草本である。

苗は発芽床で養成したものを用いて, ポット苗を作製した。 使用した用土は軽石・赤玉土・腐葉土を容積割合で $3: 1: 1$ に 混ぜ合わせたものである。発芽床の容器は発砲スチロールの 箱を用いた。播種の方法は, 用土を箱の 3 分の 2 の深さまで 入れ，表面を平らにならし，その上にミズゴケ粉を用土が見 えなくなるまで敷き詰めた。その上にさらに用土をミズゴケ 粉が見えなくなる程度に振りかけて, 砕石で表面を覆った。 砕石の量は, 表面を砕石が一重に覆うようにした。そこに草 本の種子を振りかけ, 灌水し種子を砕石の隙間に落とし込ん だ。なお，ミズゴケ粉を敷いたのは種子の養分が少ないため, 発芽当初の実生が乾燥枯死するのを防ぐためである。実生が ある程度生長した後, 直径 $9 \mathrm{~cm}$ のビニールポットに移植し た。 
表-1 植栽種の年度別の導入数と生態 ${ }^{4,8,9}$

本報の結果の分析には 2005 年植栽分とタチギボウシの植栽 3 年分の個体のみを用いた。

\begin{tabular}{|c|c|c|c|c|c|c|c|c|}
\hline \multirow{2}{*}{ 和名 } & \multirow{2}{*}{ 学名 } & \multirow{2}{*}{ 科 } & \multicolumn{3}{|c|}{ 植栽数 } & \multirow{2}{*}{ 生育地 } & \multirow{2}{*}{ 開花時期 } & 魅力 \\
\hline & & & 2005年 & 2006年 & 2007年 & & & (花の色 食べ方 効果等) \\
\hline モミジガサ & Parasenecio delphiniifolia & キク & & & 13 & 山地の森林 & 8〜10月 & 山菜(おひたしや天ぷら等 \\
\hline サワギキョウ & Lobelia sessilifolia & キキョウ & 10 & & & 山野の湿った草原 湿原 & 8〜9月 & 青紫色の花 \\
\hline エゾカワラマツバ & Galium verum v. trachycarpum & アカネ & & 20 & 12 & 低地 山地の草原や河原 & 7〜10月 & 黄色の花 \\
\hline ウド & Aralia cordata & ウコギ & & 29 & 8 & 崩壊地 山地の草原 & 8月 & 山菜(味増あえや佃煮等) \\
\hline ヤナギラン & Epilobium angustifolium & アカバナ & 10 & 4 & & 草原 荒地 & 7〜8月 & 紅紫色の花 \\
\hline エゾミソハギ & Lythrum salicaria & ミソハギ & 10 & 36 & & 泥炭地 低地の湿地 & 8月 & 紅紫色の花 \\
\hline センダイハギ & Thermopsis lupinoides & マメ & & & 13 & 海岸の砂地や砂丘 & 5〜8月 & 黄色の花 \\
\hline トリアシショウマ & Astilbe thunbergii v. congesta & ユキノシタ & 10 & 100 & 12 & 山地の林内や草原 & 7〜8月 & 山菜(煮物やゴマあえ等) \\
\hline エゾノキリンソウ & Phedimus kamtschaticum & ベンケイソウ & & 10 & 7 & 海岸や山地の乾いた所 & 7〜 8月 & 黄色の花 \\
\hline サンカヨウ & Diphylleia grayi & メギ & & 10 & & 低地〜山地の林内 & 6〜7月 & 白色の花 \\
\hline シラネアオイ & Glaucidium palmatum & キンポウゲ & & 2 & 12 & 低地〜山地の明るい林の下 & 5〜 7月 & 淡紅紫色の花 \\
\hline ベニバナヤマシャク & Paeonia obovata & キンポウゲ & & 5 & & 低山帯の林内 & 5〜 7月 & 淡紅色の花 \\
\hline エゾカワラナデシコ & Dianthus superbus & ナデシコ & 10 & 50 & 14 & 低地 海岸の草原 & $6 \sim 9$ 月 & 淡紅色の花 \\
\hline ヒトリシズカ & Chloranthus japonicus & センリョウ & & & 11 & 丘陵〜低山の林内 & 4〜 5月 & 白色の花 \\
\hline ギョウジャニンニク & Allium victorialis v. platyphyllum & ユリ & 10 & 35 & 13 & 低地〜山地の林内 & 6〜7月 & 山菜(強精効果) \\
\hline タチギボウシ & Hosta rectifolia & ユリ & 10 & 18 & 13 & 低地〜山地の湿原や草原 & 7〜8月 & 山菜(おひたしや天ぷら等 \\
\hline ミズバショウ & Lysichiton camtschatcense & サトイモ & & & 12 & 低地〜山地の湿地や水辺 & 5〜7月 & 白色の花 \\
\hline
\end{tabular}

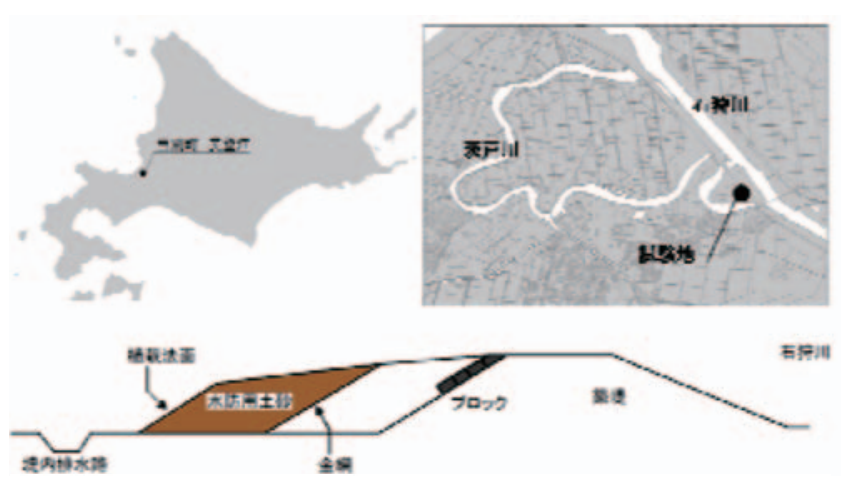

図-1＼cjkstart施工地位置(石狩川法面緑化試験堤防)および断面図

\section{2 施工方法}

施工は直径 $3 \mathrm{~m}$ の円内(ユニット)に 2005 年は 7 種 7 個の ポット苗を植栽した。2006 年と 2007 年は同種が極力 2 組以 上入らないよう, ポット苗を 1 つのユニットにつき, 10 個程 度植栽した。2005 年, 2006 年, 2007 年の 3 年間でそれぞれ, 10 ユニット 7 種 70 個, 32 ユニット 13 種 321 個, 14 ユニ ット 12 種 140 個を植栽した。また, マルチング材には流木 の木片チップを使用して，約 $10 \mathrm{~cm}$ 厚で敷き詰めた。

\section{3 追跡調查}

植栽後には毎年 3 回，定着状況と葉の広がりを継続的に調 查した。今回分析には 2005 年導入の施工後 3 年間のデータ と, 生長量の比較のため, ほぼ同数植栽されているタチギボ ウシの各植栽年分の固体データを用いた。2005 年のデータを 用いるのは，種別の植栽本数が全て同じためである。

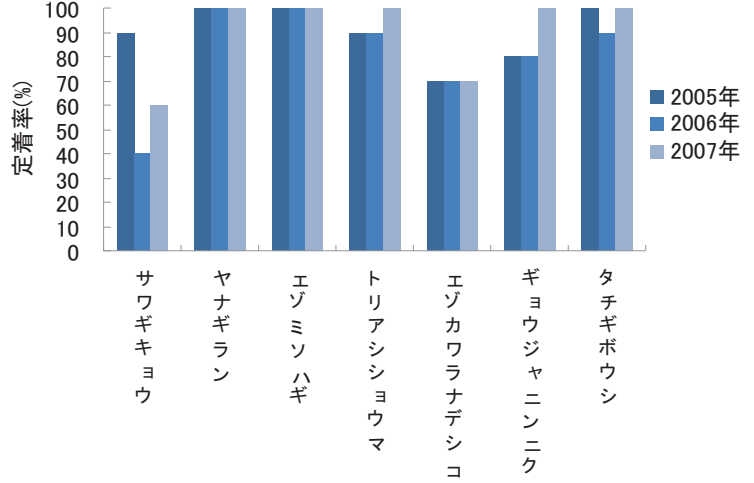

図-2 施工後 3 年間の種別の定着率 $(\%)$

\section{4. 追跡調查結果}

\section{1 定着状況}

追跡調査で得られたデータから種別の定着率と合計被覆面 積，優占率をそれぞれ求めた。まず，定着率を図-2 に示す。 確認が困難な時期もあるため, 年に一度でも確認できたもの は定着していると判断した。サワギキョウのみ 3 年目の時点 で $60 \%$ と比較的低かったが, ほぼ全ての種が高い定着率を示 した。また，カワラナデシコ，エゾミソハギ，タチギボウシ 等の開花や結実が確認できた(写真-1，写真-2)。

\section{2 被覆状況}

次に合計葉面積を図-3 に示す。葉面積は計測した葉の長径 と短径の積で概算した。夏季に最大となり，秋季に近づくと 減少する傾向がみられた。また, 最大值は年々増加していき, 植栽 3 年目には植栽 1 年目と比べ約 3 倍近い值となっていた。 図-4は 2008 年 7 月時点のタチギボウシの導入年度別の長径, 
短径の相関である。導入年度ごとに長径および短径がグルー プ化しており，この図からも草本が年々生長し，葉面積が増 加することが読み取ることができる。

\section{3 浸食状況}

施工後 3 年間で試験地域一帯では最高 $42 \mathrm{~mm} /$ 日の降雨が あった 9)。なお，降水量は気象庁のデータを用いている。し かし浸食を防ぐために敷き詰めた木片チップの流失は確認さ れず，また，導入した草本が定着して安定した法面となって いた(写真-3)。

\section{4 優占状況}

優占率を図-5 に示す。優先率は合計葉面積の比率で概算し た。優占率は調査を行なうごとに変化していた。春はギョウ ジャニンニク, 夏にはヤナギラン, トリアシショウマやエゾ ミソハギ，秋はカワラナデシコとタチギボウシが優占してい た。前年度に高い優占率を示しても次年度には減少している 種もみられた。

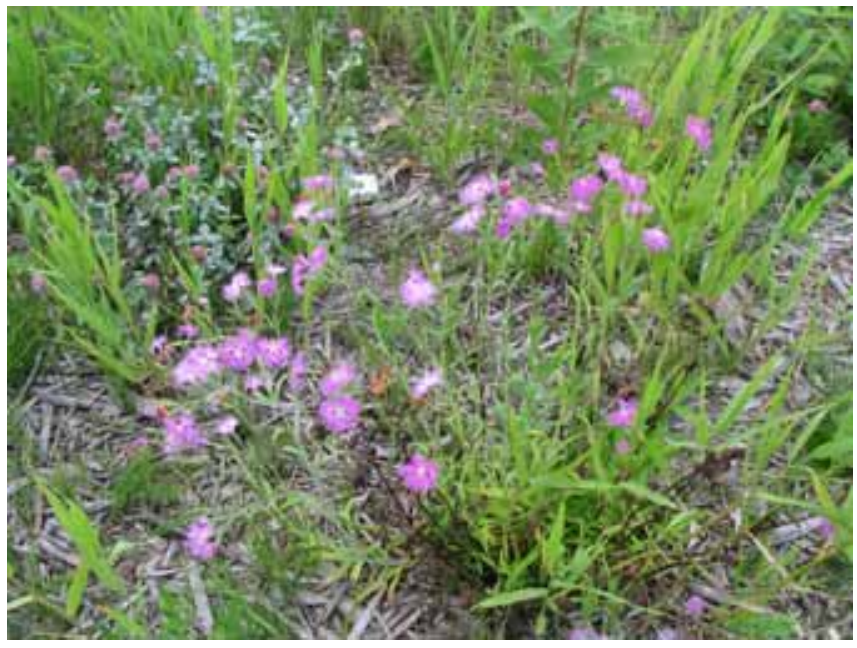

写真-1 カワラナデシコの花(2008 年 7 月 16 日撮影)

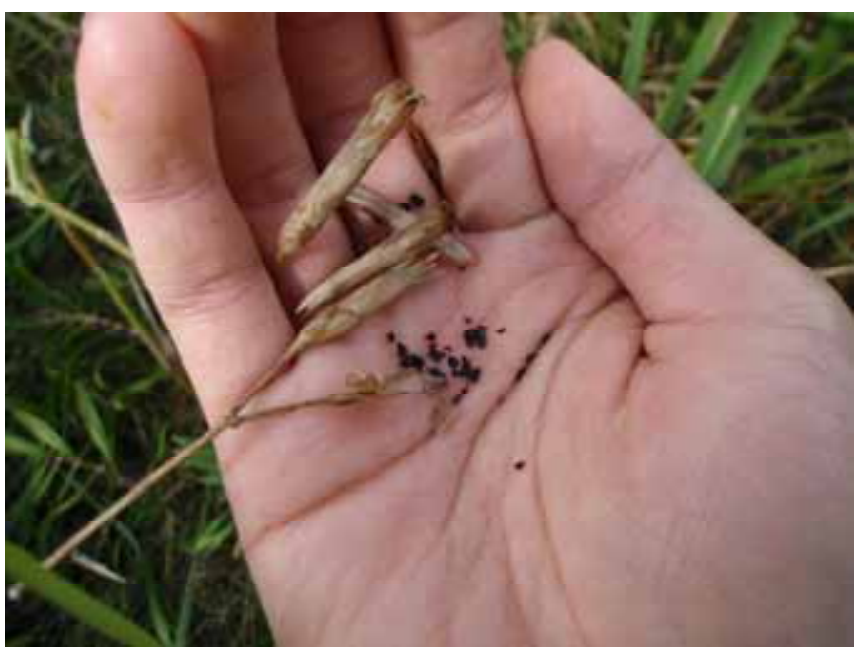

写真-2 カワラナデシコの種子 (2008 年 9 月 24 日撮影)

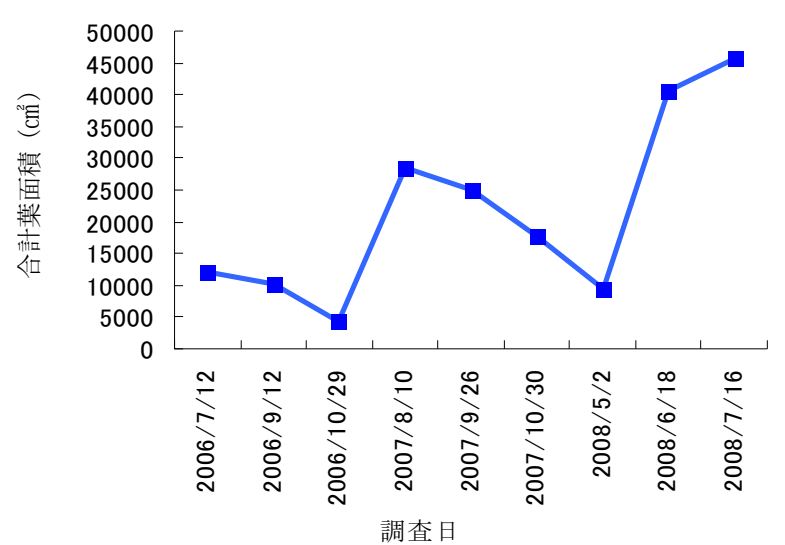

図-3 合計葉面積 $\left(\mathrm{cm}^{2}\right)$

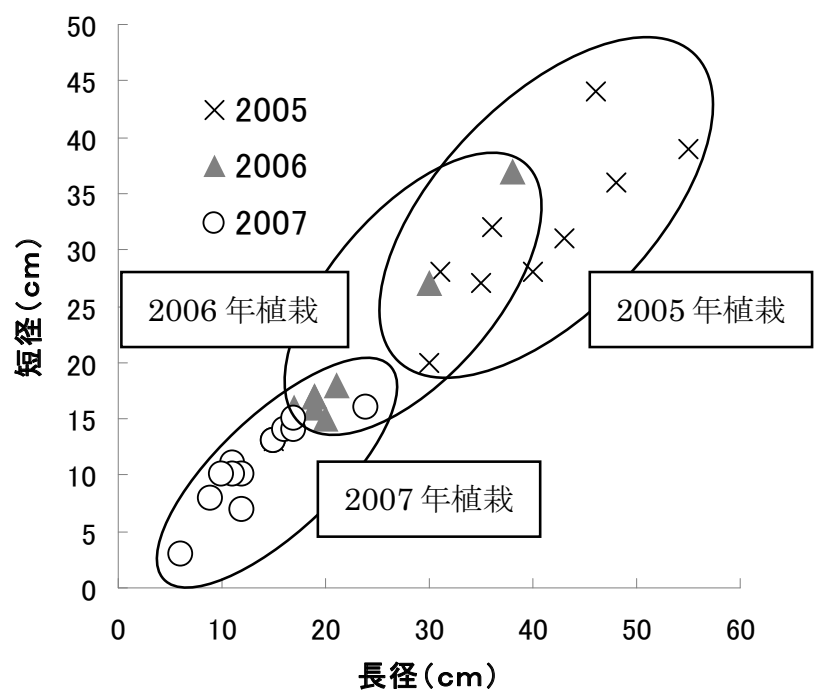

図-4タチギボウシの導入年度別の長径，短径

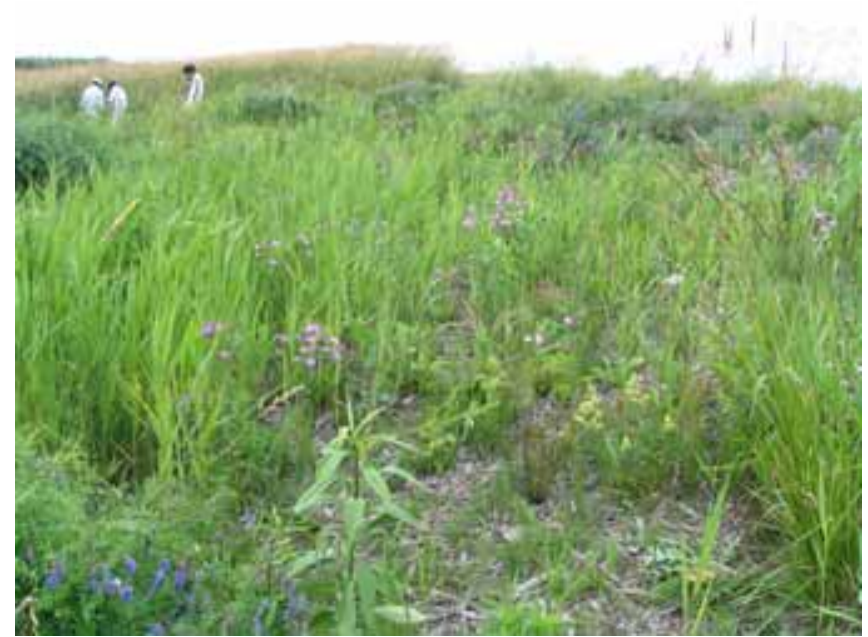

写真-3 草本が定着し安定した法面(2008 年 7 月 16 日撮影) 


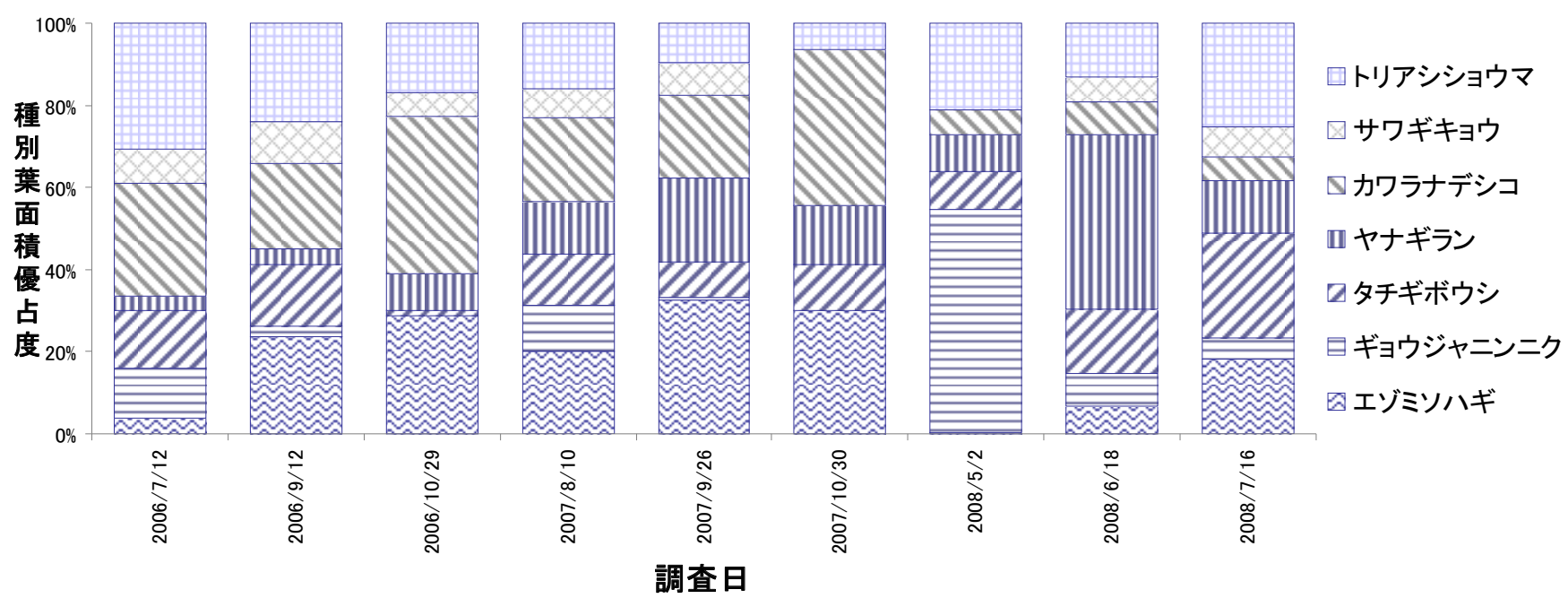

図-5 種別優占率(\%)

\section{5. 考察}

\section{1 侵食防止機能}

施工後 3 年目の時点では土畩流失は確認される事なく侵食 防止機能を果たしていた。また, 今回の試験で植栽された在 来草本のポット苗は，多くが定着していた。これらの中には 花を咲かせ, 結実している種も確認された。今後植栽した草 本が繁殖していくことにより，マルチングが風化した後も法 面の侵食防止機能を維持していけると考えられる。

\section{2 生物多様性の保全}

堤防法面では治水の安全性の面から，基本的には樹木の植 栽を行うことができない。しかし，草本であれば植栽するこ とは可能であるため, 堤防法面の緑化で生物多様性の保全を 考慮する際には，今回の植栽方法は適していると思われる。

上記に示した通り, 今後は植栽した草本が繁殖していくこ とが期待できる。今回の植栽は遺伝子のレベル(地域性)の生 物多様性まで考慮しているため, 将来的には試験地を核とし て植栽を行なった草本が分布を拡げ, 地域固有の生態系が確 立されることが期待できる。

5.3 河川景観の向上

イネ科草本を主体とした従来の外来種の堤防法面を在来草本 の多様な植生に転換したことにより，種組成が単調なものか ら多様なものとなった。それだけではなく, 時期ごとに各種 の優先率が変化していること, 植栽した草本の開花時期が 4 月から 10 月にわたることから, 積雪のある冬季を除き, 1 年を通して季節感を感じることができ, 魅力ある空間となっ ている。
5.4 住民参加による環境学習とコスト軽減

近年，住民の緑化への関心が高まりつつあり，様々な緑化 イベントが行なわれている。今回行なった草本のポット苗植 栽は吹付工のように機械等使わず，比較的簡単に緑化を行な うことができるため, 環境学習として住民参加には適してい ると思われる。また, 親しまれている草本を導入することで, さらに住民参加の可能性を促すことができる。それだけでは なく, 住民が植栽後も継続的に維持管理に参加することで, コストの軽減にも期待できると考えられる。

\section{引用文献}

1）細木大輔・中村勝衛・亀山章（2008）湿潤な切土法面におけ る外来緑化草本と先駆樹種を用いた播種工の成果比較, 日本 緑化工学会誌，34（2）：384-394.

2) 福田尚人 (2007) 北海道の自生種導入事例と今後の課題, 日 本緑化工学会誌，32（3）:415-420.

3）入山義久 - 三輪哲哉・高山光男・鈴木玲 $(2009)$ 北海道にお ける地域性苗の生産および施工事例と今後の課題, 日本緑化 工学会誌，34（4）：603-606.

4) 伊藤浩司 (1982) 北海道の高山植物と山草, 誠文堂, $230 \mathrm{pp}$.

5）環境省（2007）第三次生物多様性国家戦略, $277 \mathrm{pp}$.

6）日本緑化工学会編（2005）環境緑化の事典, 朝倉書店, pp. 237-261.

7）岡村俊邦 (2004) 生態学的混播 - 混植法の理論 実践 評価一 住民参加による自然に近い樹林の再生法一, 石狩川振興財 団, $72 \mathrm{pp}$.

8）佐藤考夫 - 小林隆正 - 久保秀樹（1995）新版北海道山菜図鑑, 亜璃西社, $311 \mathrm{pp}$.

9）梅沢俊（2007） 新北海道の花, 北海道大学出版会, $462 \mathrm{pp}$.

(2010. 7. 24 受理) 